\title{
Article
}

\section{UAV based Crop Water Stress Index for wetland habitats}

\author{
Wojciech Ciężkowski ${ }^{1, *}$, Jacek Jóźwiak ${ }^{1}$, Sylwia Szporak-Wasilewska ${ }^{2}$, Małgorzata Kleniewska' ${ }^{1}$, \\ Tomasz Gnatowski ${ }^{3}$, Piotr Dąbrowski ${ }^{3}$, Maciej Góraj ${ }^{1}$, Jan Szatyłowicz ${ }^{3}$, Stefan Ignar ${ }^{1}$ and \\ Jarosław Chormański ${ }^{1}$ \\ 1 Department of Hydraulic Engineering, Faculty of Civil and Environmental Engineering, Warsaw \\ University of Life Sciences - SGGW, Nowoursynowska 166, 02-787 Warsaw, Poland; \\ w.ciezkowski@levis.sggw.pl (W.C.); j.jozwiak@levis.sggw.pl (J.J.); malgorzata_kleniewska@sggw.pl (M.K.); \\ m.goraj@levis.sggw.pl (M.G.); s.ignar@levis.sggw.pl (S.I.); j.chormanski@levis.sggw.pl (J.C.) \\ 2 Water Center Laboratory, Faculty of Civil and Environmental Engineering, Warsaw University of Life \\ Sciences - SGGW, Nowoursynowska 166, 02-787 Warsaw, Poland; s-szporak@levis.sggw.pl \\ 3 Department of Environmental Improvement, Faculty of Civil and Environmental Engineering, Warsaw \\ University of Life Sciences - SGGW, Nowoursynowska 166, 02-787 Warsaw, Poland; \\ tomasz_gnatowski@sggw.pl (T.G.), piotr_dabrowski@sggw.pl (P.D.), jan_szatylowicz@sggw.pl (J.S.) \\ * Correspondence: w.ciezkowski@levis.sggw.pl; Tel.: +48-22-593-53-07
}

\begin{abstract}
Droughts occurring more and more frequently in recent years are usually associated with progressive climate changes. Modern monitoring methods is mainly associated with agricultural use due to the high market demand for services protecting against agricultural losses. In natural wetland ecosystem this problem is neglected which is probably due to fact that this are ecosystems rich in water by definition. Nevertheless this droughts might become a problem of wetlands, whose good condition depends on adequate hydration. Therefore this study focused on determination Crop Water Stress Index (CWSI) for natural heterogeneous wetland habitats. CWSI based on remotely sensed land surface temperature and associated basic meteorological (air temperature and humidity) measurements. CWSI was calculated based on high resolution LST measurements from UAV platform and compare with on ground measurements of soil moisture, CCI, fAPAR and meteorological conditions. Results shows that CWSI properly shows water condition of plants in measured habitats and revels high importance of metrological conditions during data acquisition.
\end{abstract}

Keywords: CWSI, , Natura 2000, thermal remote sensing, wetlands, land surface temperature

\section{Introduction}

Droughts occurring more and more frequently in recent years are usually associated with progressive climate changes [1-5] and cause serious damage to the environment as well as the economy. As these phenomena are becoming more and more intense covering larger and larger areas, a lot of attention is paid to them in scientific works, which leads to the development of new tools designed to struggles drought. A key element in the decision-making process aimed at avoiding or reducing the effects of droughts is their monitoring [6-15]. Various types of drought can be distinguished. Meteorological drought occurs as a result of the lack of atmospheric precipitation or such deficiency, which in combination with high air temperature, leads to an advantage of the amount of evapotranspiration over the amount of precipitation. A soil drought means a shortage of water available for plants. A hydrological drought consists in lowering of the level of groundwater, at which the supply of surface water through groundwater ceases and a drop in water levels and flows in rivers, and even drying of smaller streams, are observed.

There are multiple indices used to identify and assess the intensity of a drought, and their characteristics and classifications are available in the literature [6,16-22] In the case of a meteorological drought, there are methods such as: Standardised Precipitation Index [23-26], 
Relative Precipitation Index [6], Effective Drought Index [27-29], Climatic Water Balance [6] and Standardised Climatic Water Balance [30].

In order assess the occurrence and intensity of an agricultural drought, the following indexes are used, among others: Soil Moisture Index [31,32] or Crop Water Stress Index [33], with wide application possibilities [34], e.g. in determining the needs of irrigating agricultural and horticultural crops [35,36]. In addition to agricultural crops, CWSI is also used to assess the water status of trees used for agriculture: fruit orchards [37,38], olive [39], and almond trees [40].

The development of modern monitoring methods is mainly associated with agricultural use due to the high market demand for services protecting against agricultural losses. So far, no extensive research has been carried out in wetland areas particularly susceptible to changes in their water balance, which is probably due to the fact that wetland habitats are ecosystems rich in water by definition, while the groundwater level on such sites should remain close to the soil surface throughout the whole year. However, ongoing climate changes mean that plant water stress has negative effects not only on crops; this also becomes a problem of wetlands, whose good condition depends on adequate hydration, while plant stress associated with drying results directly from the disturbance of water conditions in the peat where they are formed. The disturbance of these conditions mainly by water table lowering leads to the peat subsidence due to changes of the physical conditions and mineralisation of organic matter by enhanced rates of microbial decomposition [41]. Those processes have caused the reduction of peat porosity [42,43], which consequently results in a process of degradation of the habitat associated with the disappearance of species of plants characteristic e.g. for habitat 7230, such as Valeriana simplicifolia, Epipactis palustris, Eleocharis quinqueflora, as well as moses such as Limprichtia cossonii and Campylium stellatum, or, in the case of habitat 7140, the species of Scheuchzerietalia palustris order, Caricetalia nigrae order, ScheuchzerioCaricetea class - Comarum palustre, Eriophorum angustifolium, etc. The reduction of the peatlands's water capacity and the increase in air content and soil temperature result in increased $\mathrm{CO}_{2}$ emission to the atmosphere [44,45]. Wetlands in good condition are interesting ecosystems fulfilling an important function in water management as regulators of water circulation, for which the important water balance elements include snow retention [46], flood retention [47-49], evapotranspiration [50] and interception [51,52]. Their disturbance, resulting from the impact of progressive climate changes on the natural environment [53], has a significant impact on reducing the water retention of the catchment, while the protection of wetlands constitutes the subject of multiple international conventions (Ramsar Convention on Wetlands, Bird and Habitat Directives), part of wetlands is included in Natura 2000 network areas. For this reason, the identification of the best methods for identifying the risk of drying in wetland areas using modern remote sensing techniques is being expected by teams responsible for the protection and management of the natural environment. Due to the strong relationship between soil moisture content and the surface temperature, thermal remote sensing exhibits a large potential for searching for the water stress indexes [54-56].

The main purpose of this study is the application of high-resolution thermal images from the UAV (Unmanned Aerial Vehicle) platform to determine CWSI (Crop Water Stress Index) on Natura 2000 habitats with codes 7140 (transition mires and quaking bogs) and 7230 (alkaline fens) in Poland. The index was originally developed in the area of agricultural crops [57]. Therefore, to check the possibility of using CWSI for natural ecosystems in the temperate climate zone, reference measurements were carried out during the UAV flights, including: soil moisture, relative Chlorophyll Content Index (CCI) and a fraction of Absorbed Photosynthetically Active Radiation (fAPAR).

\section{Materials and Methods}

\subsection{Study site}




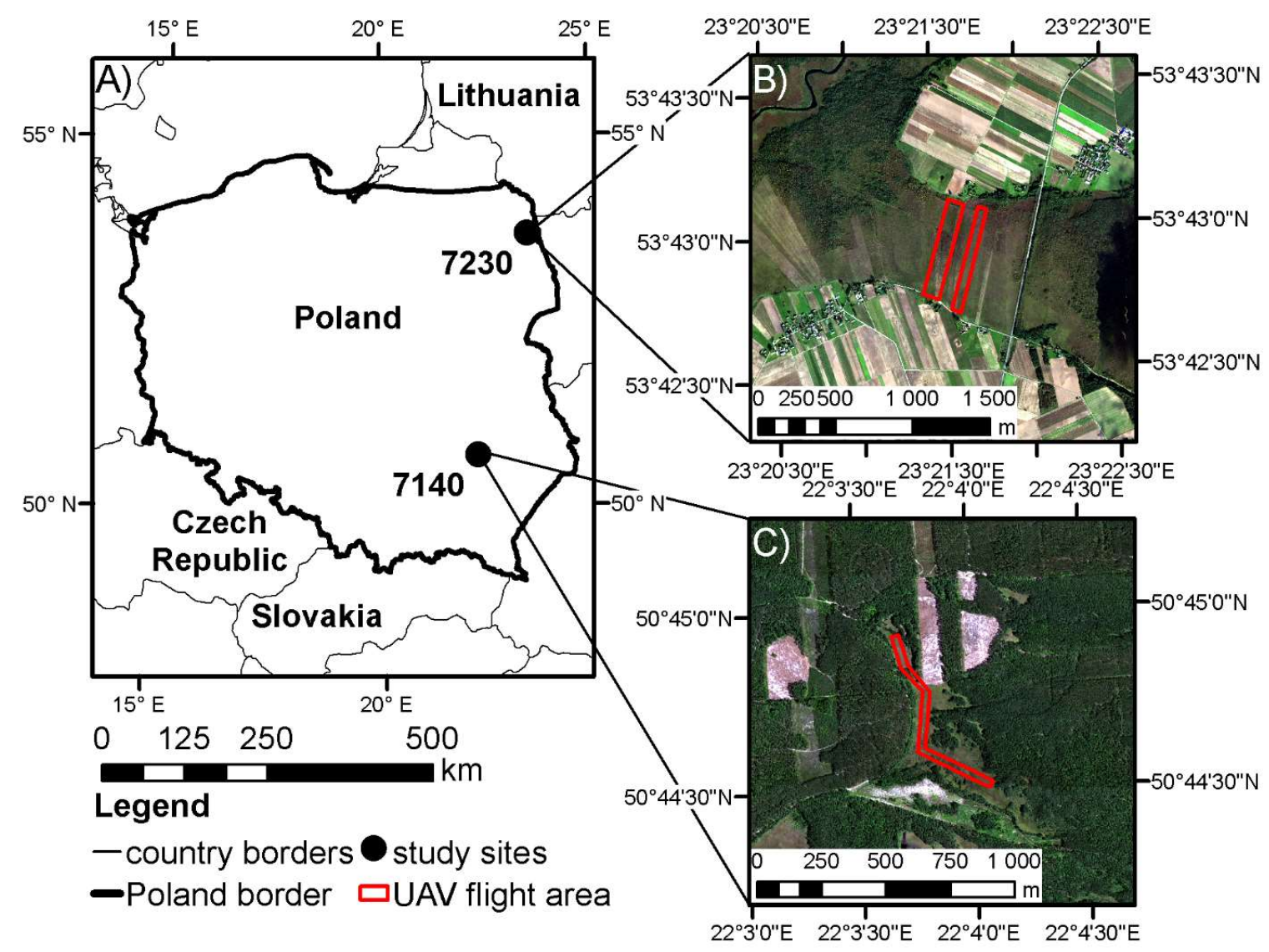

Figure 1. Study sites location: A) both study areas location in Poland, B) UAV flight area for habitat 7230 in the Biebrza National Park, C) UAV flight area for habitat 7140 in the Janów Forest Landscape Park

The research was conducted on two natural habitats of Natura 2000 (Figure 1). The research of habitat 7230 was carried out in the Biebrza National Park area located in north-eastern Poland during 2016 and 2017 vegetation seasons. The research of habitat 7140 was carried out in the Janów Forest Landscape Park area in south-eastern Poland during the 2017 vegetation season.

\subsubsection{Biebrza National Park (Habitat 7230)}

Research for habitat 7230 was carried out in the Upper Biebrza Valley in the area of Biebrza National Park (Figure 1B). According to Natura 2000, this is an area with code PLH200008 covered by the Habitats Directive. The Upper Biebrza Valley is a north-eastern part of the Biebrza Proglacial Stream Valley which together with sandurs adjoining from the north currently constitutes the largest lowering of north-eastern Poland with a length of approx. $150 \mathrm{~km}$ and an area exceeding $2600 \mathrm{~km}^{2}$. The Proglacial Stream Valley area constitutes the largest complex of natural peatlands in Central Europe. In relation to the adjacent areas, it has different thermal and humidity characteristics of the air. This is due to the overlap of climate features associated with the vast areas of peatlands and the main features of north-eastern Poland's climate, with an average annual temperature of $6-7^{\circ} \mathrm{C}(1971$ 2000) [58]. The average annual precipitation from the multiannual term of 1971-2000 is $550-600 \mathrm{~mm}$ in this area [58], while the duration of the snow cover lasts from 90 to 110 days. The research was carried out in the area near the Szuszalewo village characterised by extensively exploited alkaline peatlands, currently one of the most endangered natural habitats in Poland [59]. In case of the alkaline peatlands, the groundwater table usually remains at or slightly above the ground surface in optimal 
conditions. The habitat is characterised by low fertility and high content of calcium ions. The dominant types of vegetation are moss-sedge communities (Scheuchzerio-Caricetea nigrae community) characterised by a large floral richness with a large share of rare and protected species, such as Liparis loeselli, or plant species from Menyantho trifoliatae-Sphhagnetum teretis, Caricion davallianae, Caricetum rostratae, and Caricetum paniceo-lepidocarpae communities. A very important group of plants within habitat 7230 are mosses, part of which are glacial relics. Changes in water relations, as well as succession towards forest and shrub communities, pose the greatest threat to the habitat.

\subsubsection{Janów Forest Landscape Park (Habitat 7140)}

Research for habitat 7140 was carried out in the Janów Forest, which, together with the neighbouring Solska Wilderness, is one of the largest forest complexes in Poland (Figure 1C). According to the physiographic division of Poland [60], this area is located in the mesoregion of the Biłgoraj Plain called Puszczańska, which is a part of the Sandomierz Basin. The studied area lies in the Lublin district [61], relatively warm, with an average annual air temperature of $7-8^{\circ} \mathrm{C}(1971-2000)$ [58]. The average annual precipitation amounts to 550-600 $\mathrm{mm}$ (1971-2000) [58] while the time of snow cover deposition amounts to 80-90 days. The area of the Janów Forest mainly consists of forest habitats, where the largest area is occupied by mixed wet coniferous forest and fresh coniferous forest. Aquatic-peat and aquatic communities are characterised with the greatest floristic richness. Habitat 7140 (transition mires and quaking bogs), within which the research was carried out, constitutes approximately 400 ha of the area of the Janów Forest. They are mainly peat-filled norunoff land lowerings with a groundwater table arranged in optimal conditions at or slightly above the ground surface. Vegetation primarily consists of a moss and herbaceous layer, where the moss layer is composed mainly of sphagnum moss and proper mosses. Usually, one or two species of plants predominate in the habitat. In Janów Forest, there are species of plants from Eriophoro angustifolli-Sphagnetum recurvii, Caricetum rostratae, Caricetum lasiocarpae, Eriophorum vaginatumSphagnum fallax or Rhynchosporetum albae communities. Changes in water conditions, as well as trees and shrubs encroachment open peatlands in the conditions of lowering the groundwater table, pose the greatest threat to habitat 7140 .

\subsection{UAV acquisition and processing}

Land surface temperature (LST) was recorded using a thermal camera installed on the UAV platform in eleven measuring sessions (a detailed list is presented in Table 1). The UAV measurement platform was constructed on the basis of DJI S1000+ frame (DJI, China) equipped with PIXHAWK autopilot (3D Robotics, USA) having a built-in IMU (Inertial Measurement Unit) system. GNSS navigation data was collected using Tersus-GNSS Precis BX306 GNSS device (Tersus GNSS China, China) enabling dual-frequency signal recording in both GPS and GLONASS systems. The temperature data logger was Optris PI640 radiometric camera (Optris GmbH, Germany) mounted on a 2-axis stabilising system. Additionally, in order to identify details and to select GCP (Ground Control Points), an RGB image was recorded with a camera included in the equipment of UAV DJI Phantom 3 Professional platform (DJI, China).

Table 1. Acquisition dates and times, numbers of transect and flights per transect for both measured habitats.

\begin{tabular}{ccccc}
\hline Area & Date & $\begin{array}{c}\text { Number of } \\
\text { transect }\end{array}$ & $\begin{array}{c}\text { Flights per } \\
\text { transect }\end{array}$ & Time of flights \\
\hline & 24.07 .2016 & & 3 & $11: 00-3: 30$ \\
& 07.09 .2016 & 2 & 2 & $12: 00-2: 00$ \\
Biebrza National & 15.09 .2016 & & 2 & $11: 00-2: 00$ \\
\cline { 2 - 5 } Park (7230) & 08.06 .2017 & & 1 & $11: 50-12: 50$ \\
& 07.07 .2017 & 2 & 1 & $10: 20-1: 30$ \\
& 16.08 .2017 & & 1 & $10: 00-12: 15$ \\
\hline
\end{tabular}




\begin{tabular}{|c|c|c|c|c|}
\hline & 14.07.2017 & & 3 & 11:30-2:00 \\
\hline Janów Forest & 01.08.2017 & & 3 & 11:40-3:00 \\
\hline Landscape Park & 19.07.2017 & 1 & 1 & $12: 30$ \\
\hline \multirow[t]{2}{*}{ (7140) } & 30.08.2017 & & 3 & $11: 50-2: 00$ \\
\hline & 09.09.2017 & & 3 & $11: 00-12: 30$ \\
\hline
\end{tabular}

Flights over research transects were carried out autonomously along the planned routes, which ensured the repeatability of the area range that was photographed during subsequent flights. The set flight parameters allowed to obtain terrain resolution not worse than $10 \mathrm{~cm} / \mathrm{px}$. Air operations were carried out in possibly stable weather conditions. In addition, each time before starting the registration process, the camera was started for at least two minutes to stabilise the internal temperature of the device remaining under voltage. During recording, the device compensates the temperature changes of the sensor in intervals between 30 and 120 seconds through self-calibration.

Raw thermal data (saved as a video file) was converted into a radiometric form using Optris Pi Connect software (Optris $\mathrm{GmbH}$, Germany). Subsequently, the individual frames of the recording were extracted. The process was carried out manually to ensure the quality of the obtained data (elimination of blurred images and saved at the time of self-calibration).

The coordinates of the projection centres of individual radiometric images were determined based on the GNSS on-board system recorded data. Then, the data set (the image-GPS position pair) was processed in Photoscan software (Agisoft LLC, Russia). The photogrammetric process consisted of generating a sparse point cloud, controlling the initially obtained model (and its possible correction), creating a dense cloud of points, creating a DSM (digital surface model) and finally constructing an orthophotomosaic and exporting it to the TIFF format.

In addition, an orthophotomap in the visible band (RGB) was prepared for each of the research transects. The flight parameters were selected to obtain source data with a terrain resolution of 4.3 $\mathrm{cm} / \mathrm{px}$. In addition, a network of photogrammetric ground control points was established in the study area. The coordinates of its individual points were measured using the GNSS RTK technique using real-time corrections of the TPP NetPRO network [62].

These points were used in the photogrammetric process to increase the internal coherence and external accuracy of the resulting orthophotomap. The obtained error of fitting on the matrix points did not exceed $3 \mathrm{px}$ at the resolution of the resultant material at the level of $5 \mathrm{~cm} / \mathrm{px}$.

The TIR orthophotomosaic was subjected to final geometric rectification in the QGIS programme based on characteristic points identifiable on the RGB orthophotomap. At least 20 points evenly distributed over part of the image covering the tested habitat were used.

\subsection{Biophysical and hydrological parameters measurements}

The measurement campaigns during which the measurements of CCI and fAPAR, as well as the moisture content of the surface soil layer, took place on the dates of the acquisition of UAV data. Totally 45 research plots with dimensions of $1 \times 1 \mathrm{~m}$ were established, in which the abovementioned measurements were carried out. The number of measurements carried out depended on the situation in the field (e.g. in September 2016, part of the research area was mown, which made it impossible to carry out measurements). The number of measurements carried out on each of the dates of research campaigns is presented in Table 2. fAPAR determines what part (fraction) of photosynthetic radiation (in the range of 400-700 $\mathrm{nm}$ ) has been absorbed by plants and used in the photosynthesis process. It expresses the ratio of photosynthetically active accumulated radiation to total radiation reaching the surface of plants. The parameter allows to assess the condition of plants and their productivity. Measurements of fAPAR were carried out using SunScan Canopy Analysis System SS1 system (DeltaT Devices, Ltd., UK) on the established study plots. Within each study plot, a total of 10 measurements of fAPAR were carried out and subsequently averaged. The CCI measurements were carried out using CCM200 chlorophyll meter (Opti - Sciences, Inc., USA), which uses transmittance measured in two wavelength ranges of $653 \mathrm{~nm}$ and $931 \mathrm{~nm}$ to estimate the relative chlorophyll content in leaves. The CCI value is directly proportional to the actual concentration of chlorophyll in the leaves. The index made it possible to observe changes in the physiological state of dominant plant 
species under the influence of phenological changes and changing humidity conditions that may have caused stress. CCI measurements were carried out for 10 specimens of each of the 1-3 dominant species found on the test plot in triplicate (on three different leaves), which were then averaged. CCI and fAPAR parameters measured for the purpose of verifying the results of CWSI.

Table 2. Numbers of fAPAR, CCI and soil moisture measurements made during UAV flights

\begin{tabular}{ccccc}
\hline Area & Date & \multicolumn{3}{c}{ Number of measurements } \\
\cline { 2 - 5 } & & fAPAR & CCI & Soil moisture \\
\hline Biebrza National & 24.07 .2016 & 45 & 45 & 41 \\
Parka (habitat & 07.09 .2016 & 26 & 26 & 26 \\
$7230)$ & 15.09 .2016 & 26 & - & 26 \\
\cline { 2 - 5 } & 08.06 .2017 & 31 & 31 & $*$ \\
& 07.07 .2017 & - & - & $*$ \\
\hline Janów Forest & 16.08 .2017 & 31 & 31 & 28 \\
Landscape Park & 14.07 .2017 & 30 & 30 & - \\
(habitat 7140) & 01.08 .2017 & - & 9 & $*$ \\
& 19.08 .2017 & - & 8 & 30 \\
\hline
\end{tabular}

* - fully saturated conditions - no soil moisture measurements

** - TDR probe malfunction due to technical problems

Measurements of moisture in surface soil layers $(0-10 \mathrm{~cm}$ layer) were carried out along measurement transects located within the studied habitats (Table 1) using the Time Domain Meter (TDR) [63]. At each $10 \mathrm{~cm}$ point of transect, the TDR probe was installed vertically from the ground surface into the soil profile. The measurements of dielectric constant $(\mathrm{Ka})$ were carried out in triplicate. The obtained result represented the average value of Ka constant in the surface soil layer. For the conversion of the dielectric constant into the value of the soil moisture content of the surface layers of habitats 7230 and 7140, the authors used their own calibration equations developed in laboratory tests in accordance with the methodology presented by $[64,65]$.

\subsection{Meteorological data measurements}

Meteorological data in the form of air temperature and relative humidity were measured using HOBO U23 Pro v2 Temperature/Relative Humidity Data Logger sensor (Onset ${ }^{\circledR}$, USA). The temperature and relative humidity sensor was mounted at a height of $2 \mathrm{~m}$, before the first UAV flights (between $9 \mathrm{am}$ and $10 \mathrm{am}$ ) and removed after their completion (between $3 \mathrm{pm}$ and $4 \mathrm{pm}$ ), the values were measured with a 10 minute time step. In addition, the temperature of the vegetation was measured over an optimally moistened surface every 30 minutes using a non-contact handheld OMEGA Os151-usb thermometer (OMEGA Engineering, INC) using a thermal infrared beam.

\subsection{CWSI calculations and meteorological background}

Thermal data obtained in the dates listed in Table 1 and meteorological data measured during the flights were used for calculating CWSI. First, the saturation vapour pressure deficit (VPD) was calculated based on air temperature and relative humidity using the following formula:

$$
\mathrm{VPD}=\mathrm{E}-\mathrm{e},
$$

where: VPD - saturation vapour pressure deficit $(\mathrm{kPa}), \mathrm{E}$ - maximum pressure of water vapour $(\mathrm{kPa})$ calculated from the following formula:

$$
\mathrm{E}=0.6108 \cdot \exp [17.27 \cdot t /(t+237.21)]
$$



formula:

where: $\mathrm{t}$ - air temperature $\left({ }^{\circ} \mathrm{C}\right)$, e - actual vapour pressure $(\mathrm{kPa})$ calculated from the following

$$
\mathrm{e}=\mathrm{RH} \cdot \mathrm{E},
$$

where: RH - relative air humidity (-). The saturation vapour pressure deficit calculated in this way is used to determine non-water-stressed baseline (NWSB). NWSB shows the dependence of the difference of plant temperature (Tc) and air temperature (Ta) on VPD and is described with a following equation $[57,66]$ :

$$
\mathrm{dT}=\mathrm{m} \cdot \mathrm{VPD}+\mathrm{b},
$$

where: $\mathrm{dT}$ - difference between the vegetation temperature and air temperature $(\mathrm{Tc}-\mathrm{Ta})\left({ }^{\circ} \mathrm{C}\right)$. Knowing the equation of the NWSB, CWSI can be calculated based on the following equation $[57,66]$ :

$$
\mathrm{CWSI}=\left(\mathrm{dT}_{\mathrm{m}}-\mathrm{dTLL}\right) /\left(\mathrm{dTul}_{\mathrm{L}}-\mathrm{DTLL}\right),
$$

where: dT - difference between Ta i Tc, subscripts m, LL and UL respectively refer to: the measured difference, lower and upper limit of dT. dTLL and dTuL were calculated using the following formulas:

$$
\begin{aligned}
& \mathrm{dT}_{\mathrm{LL}}=\mathrm{m} \cdot \mathrm{VPD}+\mathrm{b}, \\
& \mathrm{dT}_{\mathrm{UL}}=\mathrm{m} \cdot \mathrm{VPG}+\mathrm{b},
\end{aligned}
$$

where: VPG - vapour pressure gradient $(\mathrm{kPa})$ determined as the difference between the maximum pressure of water vapour at a given air temperature and the maximum water vapour pressure at the air temperature elevated by factor $b$.

NWSB was determined for each of the dates in which the UAV flight was carried out. From among NWSBs designated, one equation of the day was selected for each object according to the recommendations described by $[67,68]$ : the day was sunny and with a wind speed below $6 \mathrm{~m} \cdot \mathrm{s}^{-1}$. On this basis, a NWSB from 14.07.2017 for the object located in the Janów Forest Landscape Park was used for further calculations:

$$
\mathrm{dT}=-7.42 \cdot \mathrm{VPD}+16.3
$$

and a NWSB for the Biebrza National Park from 07.07.2017 for data obtained in both years of measurements:

$$
\mathrm{dT}=-11.63 \cdot \mathrm{VPD}+21.3
$$

During the selected days, the study area was well waterd, which enabled measurements to be carried out over an optimally moisturised surface (reference for vegetation temperature measurements).

Based on the studies of the Institute of Meteorology and Water Management - National Research Institute [69] thermal and precipitation conditions in the research area in the analysed period were studied in relation to the multiannual term (Table 3). Data in Table 3 is presented in accordance with the IMGW-PIB methodology: thermal conditions in a given year are presented against the long term in accordance with the methodology suggested by [70], whereas precipitation conditions are presented according to [71].

Table 3. Temperature and precipitation in vegetation season on both study sites against multiannual sums

Biebrza National Park

Janów Forest Landscape

Park

year

2016

2017

2017 


\begin{tabular}{|c|c|c|c|c|c|c|}
\hline & $\begin{array}{l}\text { temperature } \\
\text { anomaly }\end{array}$ & $\begin{array}{l}\text { \% of } \\
\text { multiannual } \\
\text { precipitation }\end{array}$ & $\begin{array}{c}\text { temperature } \\
\text { anomaly }\end{array}$ & $\begin{array}{l}\text { \% of } \\
\text { multiannual } \\
\text { precipitation }\end{array}$ & $\begin{array}{c}\text { temperature } \\
\text { anomaly }\end{array}$ & $\begin{array}{l}\text { \% of } \\
\text { multiannual } \\
\text { precipitation }\end{array}$ \\
\hline March & $\begin{array}{l}\text { slightly } \\
\text { warm }\end{array}$ & $130-150$ & $\begin{array}{l}\text { extremely } \\
\text { warm }\end{array}$ & 200 & $\begin{array}{l}\text { extremely } \\
\text { warm }\end{array}$ & $120-140$ \\
\hline April & very warm & 100 & normal & $190-210$ & normal & $130-150$ \\
\hline May & $\begin{array}{c}\text { anomalously } \\
\text { warm }\end{array}$ & $70-90$ & normal & $110-130$ & normal & $70-90$ \\
\hline June & $\begin{array}{l}\text { extremely } \\
\text { warm }\end{array}$ & $60-80$ & $\begin{array}{c}\text { anomalously } \\
\text { warm }\end{array}$ & $150-170$ & $\begin{array}{l}\text { extremely } \\
\text { warm }\end{array}$ & $30-50$ \\
\hline July & very warm & $130-150$ & $\begin{array}{l}\text { slightly } \\
\text { warm }\end{array}$ & $110-130$ & warm & $70-90$ \\
\hline August & warm & $110-120$ & $\begin{array}{l}\text { extremely } \\
\text { warm }\end{array}$ & 100 & $\begin{array}{l}\text { extremely } \\
\text { warm }\end{array}$ & $70-90$ \\
\hline September & $\begin{array}{c}\text { extremely } \\
\text { warm }\end{array}$ & $40-60$ & warm & $175-200$ & warm & $150-175$ \\
\hline
\end{tabular}

\section{Results and discussion}

\subsection{Meteorological results}

In the area of the Biebrza National Park, the measurement periods of 2016 and 2017 differed between each other in terms of temperature and precipitation (Table 3). The year 2016 was warmer and with a lower amount of precipitation. In 2017, only August was normal in terms of precipitation; in the remaining months, precipitation significantly exceeded the norm, reaching even $210 \%$ of its value (April). In the area of Janów Forest Landscape Park in 2017, the thermal conditions were similar to those recorded in the Biebrza area, while in precipitation conditions a large variation was observed. March, April and September were humid, while May, July and August were normal, and June was very dry.

\subsection{CWSI maps}

The results of CWSI calculations were presented in the form of maps (Figures 2-4) and in the form of a box plot drawn on the basis of 1000000 randomly selected pixels from each map (Figure 5). If more than one flight was carried out over the transect in a given period, the maps were averaged on the basis of all flights carried out over a given transect. The significance of median differences in CWSI values between particular dates in both areas was checked by means of the Kruskal-Wallis test in the R environment [72]. For both areas, differences in CWSI are significant at the level of $p<0.05$.

The calculation results for the area of Janów Forest Landscape Park (Figure 2 and 5 C) show low values (median around 0) of CWSI during the first measurement campaign (14.07.2017). Then, the CWSI values reach their maximum (median approx. 0.15) during the second measurement campaign (1.08.2017). Further, the values of the CWSI gradually decrease, reaching the minimum (median around -0.06) during the last measurement campaign (09.09.2017). In this area, the values of CWSI reflect precipitation conditions prevailing in 2017 (Table 3). After humid March and April and then normal May, enough water accumulated in the soil and despite the very dry June, the CWSI values were low in the first half of July. Only then, when the water supply was exhausted, an increase in CWSI was observed at the beginning of August. The following months were characterised by the average amount of precipitation, the amount of which was sufficient to improve the condition of plants, hence the decrease in CWSI during subsequent flights in August. Measurements in September were carried out in the conditions of the groundwater level at the surface (after high precipitation), which was reflected in CWSI taking the lowest values during the entire research period. 

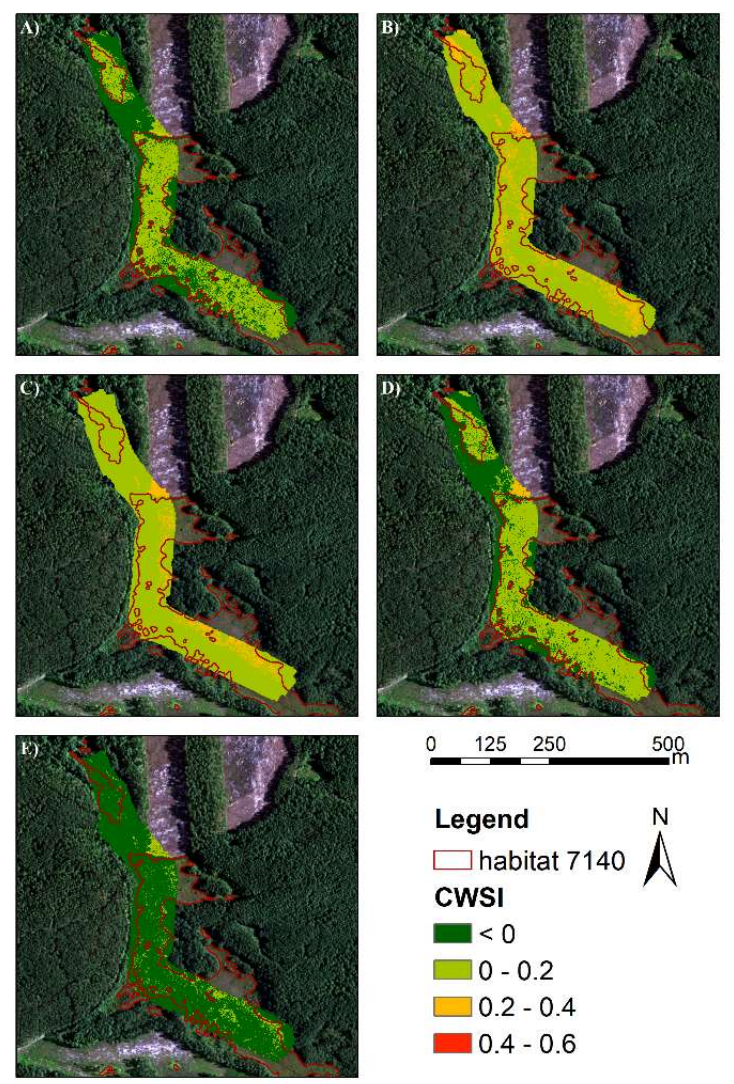

Figure 2. CWSI and habitat 7140 borders in the Janów Forest Landscape Park for 5 UAV campaigns: A) 14 July, B) 1 August, C) 19 August, D) 30 August, E) 9 September

The results for the Biebrza National Park area in 2016 (Figure 3 and 5 A) show that the lowest CWSI values were observed on 24th July (median equal to -0.013). In September, the CWSI values increased to -0.008 on 7 th September and to 0.033 on 15th September. Mowing of part of the meadow (the northern part of both studied transects and the south-western part of the western transect) at the beginning of the month had a significant impact on CWSI values recorded in September. On 7th September, freshly mown plants were still transpiring; over time, this process was less and less intense, and on 15th September, CWSI in the mown part reached maximum values. From March to August, precipitation in this area did not differ significantly from the multiannual norm (Table 3). It was not until September that precipitation was significantly lower than the multiannual average (Table 3), which caused an increase of the CWSI value on unmown areas of the studied transects (Figure $3 \mathrm{~B}$ and $\mathrm{C}$ ). 

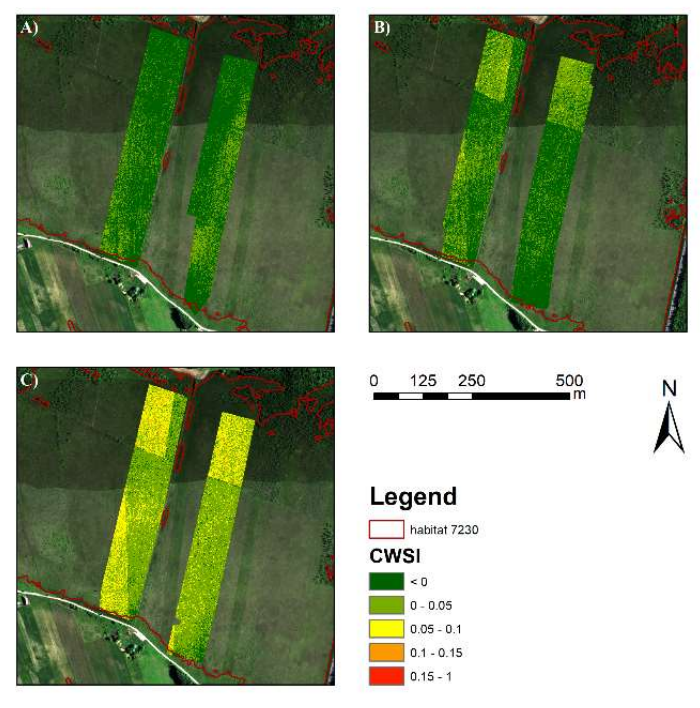

Figure 3. CWSI and habitat 7230 borders in the Biebrza National Park for 3 UAV campaigns in 2016: A) 24 July, B) 7 September, C) 15 September

The results for the Biebrza National Park area in 2017 (Figure 4 and 5 B) show that during the first measurement campaign (8th June), CWSI values were slightly above 0 (median was equal to 0.008). Then, an increase in the index was observed and on 7th July, the median amounted to 0.056 , which was the highest value during that year. During the last measurement campaign on 16th August, CWSI reached the lowest values (median equal to -0.037). Analysing CWSI values relative to precipitation (Table 3), it can be seen that from the beginning of the vegetation period, precipitation was higher than the multiannual average, which resulted in the lowest CWSI during the last measurement session. In June, despite high precipitation in the previous months, CWSI amounted above 0 , which indicates suboptimal humidity conditions. This situation was caused by anomalously high temperature (Table 3) this month, which affected the intensity of evaporation and the CWSI values obtained. CWSI values obtained in July are burdened with errors related to unfavourable conditions during the acquisition of thermal data. High clouds were present during the flight, which disturbed the measurement and, as a result, the obtained CWSI value. This situation also indicates the need to carry out measurements in ideal weather conditions.
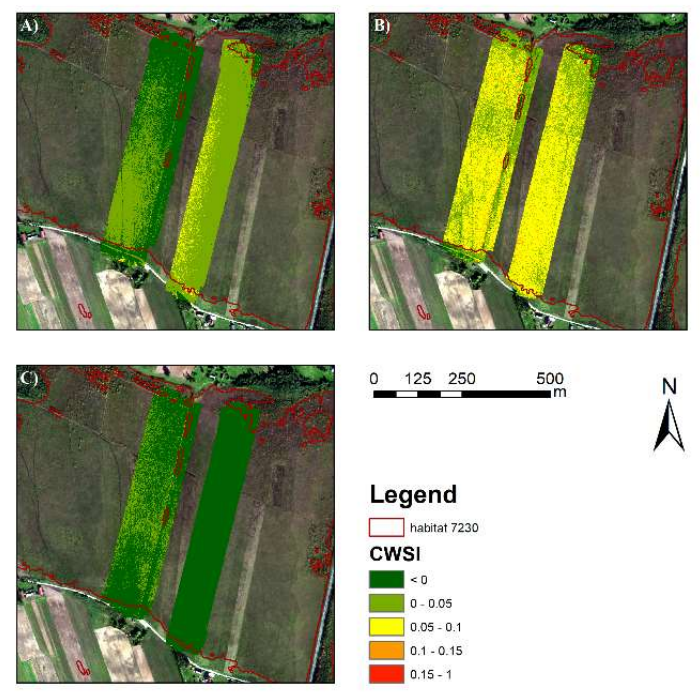

\section{Legend}

$\square$ habitat 7230

CWSI

100

D. 0.05

$\square_{0.1-0.15}^{0.05-1}$

${ }_{0.15-1}^{0.1} 0.15$ 
Figure 4. CWSI and habitat 7230 border in the Biebrza National Park for 3 UAV campaigns in 2017: A) 8 June, B) 7 July, C) 16 August
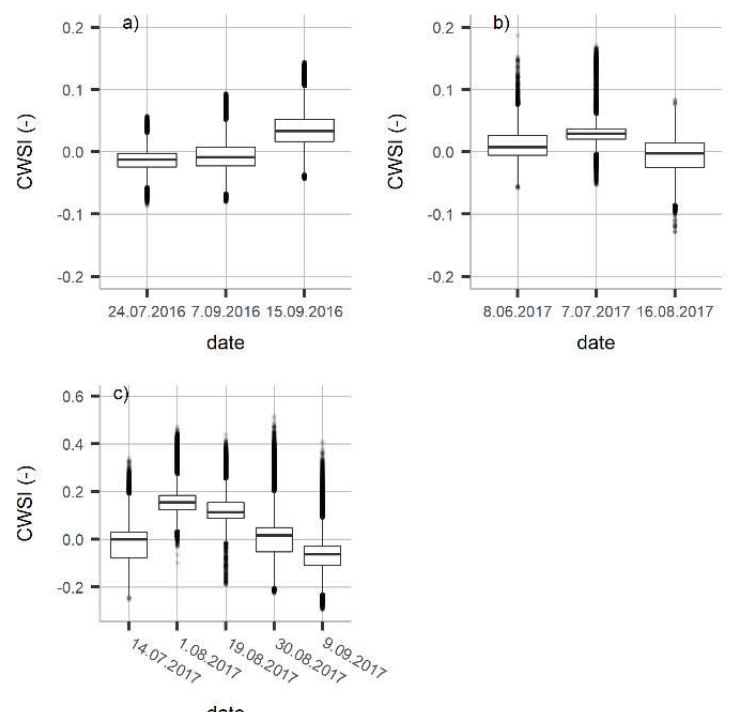

date

Figure 5. Boxplots showing distribution of CWSI for all campaigns based on 1000000 pixels randomly selected from CWSI maps for: A) Biebrza National Park 2016, B) Biebrza National Park 2017, C) Janów Forest Landscape Park 2017, boxplot shows median, the lower and upper hinges correspond to the first and third quartiles, the upper and the lower whisker is $1.5^{*}$ interquartile range

\subsection{CWSI and field measurements relation}

\subsubsection{Janów Forest site}

The CWSI values were averaged for each of the study areas where biophysical measurements were carried out in the Janów Forest Landscape Park area. The obtained values were compared with soil moisture (Figure 6), fAPAR (Figure 7) and CCI (Figure 8).

The dependence of soil moisture on CWSI is presented in Figure 6. For the three dates in which the TDR measurement was carried out, a total of 86 values were obtained. The values of CWSI and soil moisture in the measurement points were in the range from -0.17 to $0.06 \mathrm{~cm}^{3} \cdot \mathrm{cm}^{-3}$ and from 0.79 to $0.97 \mathrm{~cm}^{3} \cdot \mathrm{cm}^{-3}$ respectively, of which in 75 points the soil moisture content is above $0.9 \mathrm{~cm}^{3} \cdot \mathrm{cm}^{-3}$. Due to the small range of soil moisture values, no dependence between soil moisture and CWSI is observed. Due to the number of observations, the lack of this relationship is particularly noticeable for the results of soil moisture measurement obtained in the value zone above $0.9 \mathrm{~cm}^{3} \mathrm{~cm}^{-3}$. 


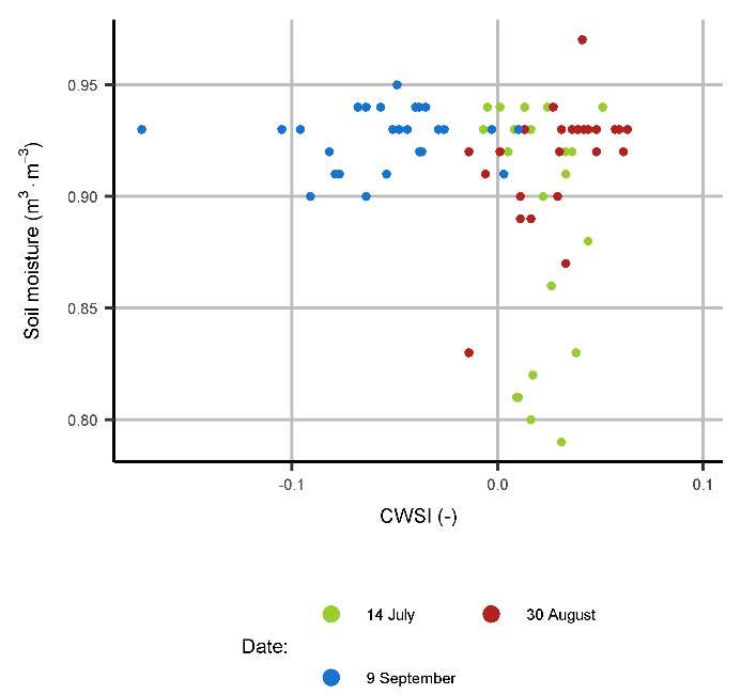

Figure 6. Dependence of soil moisture on CWSI for the Janów Forest Landscape Park

The dependence between fAPAR and CWSI indices is presented in Figure 7. The fAPAR value was measured over two dates (Table 2) and 60 points were obtained in total. The CWSI value at the examined points ranged from -0.17 to 0.06 , while fAPAR ranged from 0.08 to 0.66 . In the observed range of index values, their quadratic dependence is statistically significant at the level of $p<0.05$. The developed empirical dependence indicates that the decrease in fAPAR causes an increase in the water stress of plants expressed as CWSI.

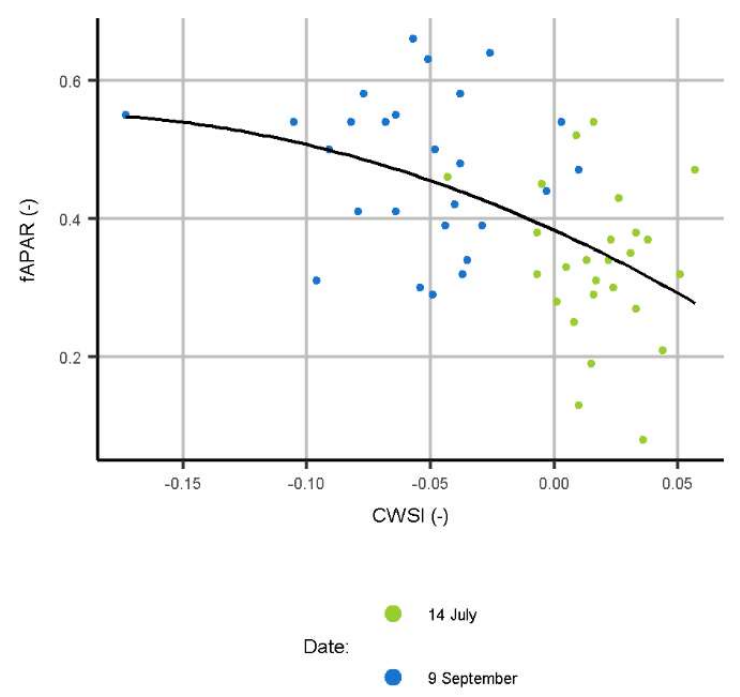

Figure 7. Dependence of fAPAR on CWSI for the Janów Forest Landscape Park

The dependence of CCI on CWSI is presented in Figure 8. CCI was measured on all UAV flight dates (Table 2) and a total of 86 points were obtained. The CWSI value at the examined points ranged from -0.17 to 0.23 , while CCI ranged from 1.1 to 18.6. The graph shows two groups of points. One of them shows CCI amounting to approx. 2 regardless of the CWSI value. For the second one, the quadratic dependence of CCI on CWSI is statistically significant at the level of $p<0.05$. In this range of variability with the increase of CWSI, an increase of CCI is observed, low values of CWSI indicate a preliminary phase of drying in which the increase of the CCI value can be explained by the decrease in the turgidity of plants. 


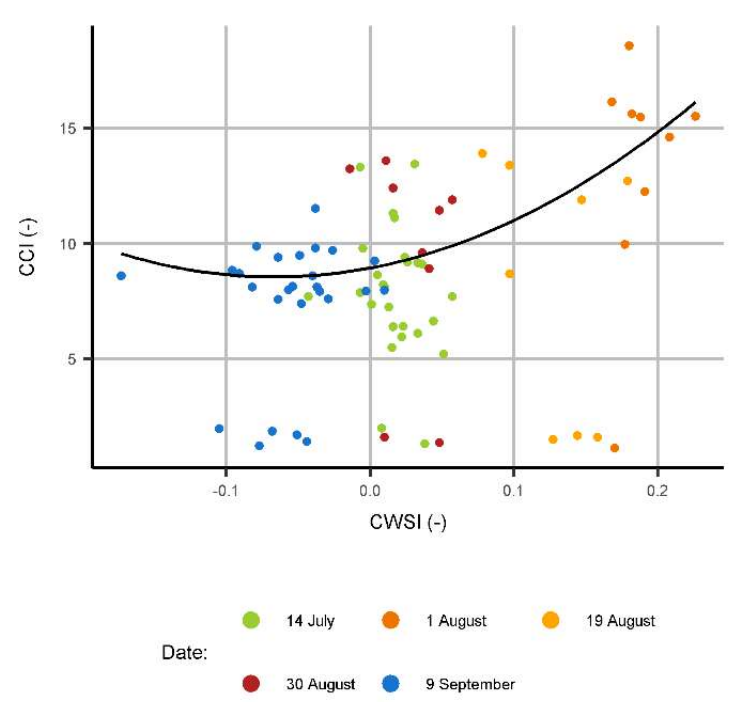

Figure 8. Dependence of CCI on CWSI for the Janów Forest Landscape Park, the black line shows the matching quadratic equation for points, where $\mathrm{CC}>3$

For the area of the Janów Forest Landscape Park, field measurements were carried out in the vegetation season of 2017. The obtained CWSI values were observed in the range from -0.3 to 0.6. They correlate with the measured biophysical parameters of plants (fAPAR and CCI). The dependence on FAPAR is inverse, which means that at higher values of CWSI, a lower value of fAPAR is observed, indicating the poorer condition of plants. However, in the studied range of variability, CWSI values correlate directly with CCI values. In this case, the increase of CCI with the increase of CWSI is related to the decrease in the turgidity of plants in the initial phase of water stress. However, no significant CWSI dependence on soil moisture is observed in long-term results taken from the whole measurement season. This is due to the fact that in the studied habitat, although some species of plants such as sphagnum mosses, often forming raised clumps at the occurrence of adverse hydrometerological conditions, start to dry quickly (especially in the upper part of the clumps created by them), thus giving higher CWSI values, yet the soil which is measured using the TDR method is still characterised by high humidity.

\subsubsection{Biebrza valley}

The CWSI values were averaged for each of the study plots where biophysical measurements were carried out in the Biebrza National Park area. The obtained values were compared with soil moisture (Figure 9), fAPAR (Figure 10) and CCI (Figure 13).

The dependence of soil moisture on CWSI in 2016 is presented in Figure 9. A total of 90 points were collected for three dates. CWSI values at the examined points ranged from -0.041 to 0.039 , while soil moisture ranged from 0.69 to $0.96 \mathrm{~cm}^{3} \cdot \mathrm{cm}^{-3}$. There was no significant dependence between CWSI and soil moisture observed. However, the results show that the average soil moisture in July amounting to $0.86 \mathrm{~cm}^{3} \cdot \mathrm{cm}^{-3}$ was higher than during the measurements carried out in September (the average for both September dates amounted to $0.82 \mathrm{~cm}^{3} \cdot \mathrm{cm}^{-3}$ ). Most of the measurement points were characterised by a CWSI value below 0 , demonstrating the lack of water stress in plants. At the same time, most of the points were characterised by soil moisture above $0.8 \mathrm{~cm}^{3} \cdot \mathrm{cm}^{-3}$, which explains the lack of correlation between these parameters. Also, the poor condition due to the drying of susceptible plants such as bryophytes, which have a significant share in the studied habitat, was not observed. 


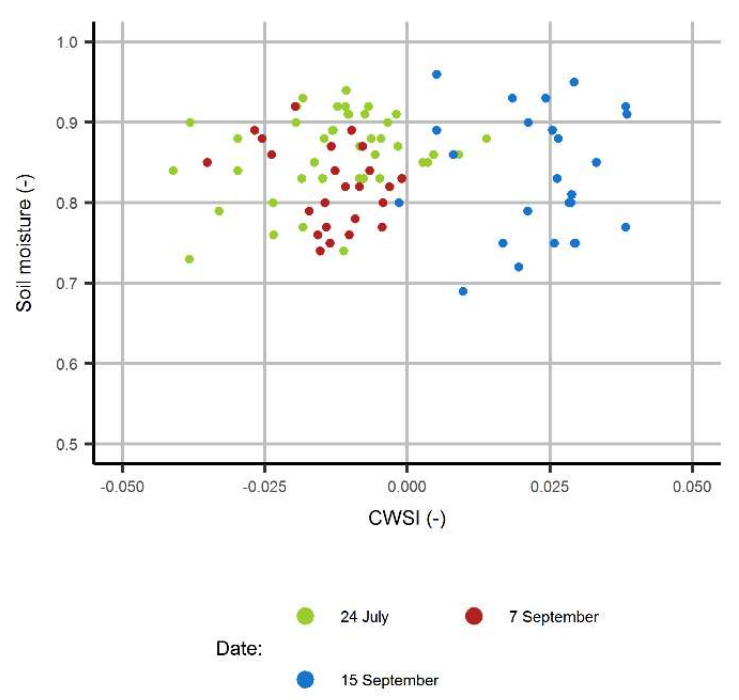

Figure 9. Dependence of soil moisture on CWSI for the Biebrza National Park in 2016

The dependence of fAPAR on CWSI in 2016 is presented in Figure 10, and for 2017 in Figure 11. In 2016 (Figure 10), a total of 89 points were measured, in which fAPAR was changing from 0.44 to 0.93 , while CWSI was changing from -0.041 to 0.033 . For two dates when points of CWSI less than 0 (24th July and 7th September) dominate, there is no dependence observable between fAPAR and CWSI. For those CWSI values indicating the lack of water stress, fAPAR is determined by other factors (e.g. botanical composition of the sample). However, for 15th September, when CWSI increased below zero, indicating water stress, a square fall in fAPAR can be observed together with the increase of CWSI. This dependence is statistically significant at the level of $\mathrm{p}<0.05$. In 2017 (Figure 11), a total of 62 points were measured, in which fAPAR was changing from 0.28 to 0.79 , while CWSI was changing from -0.065 to 0.039 . The measurements were carried out in two dates with low CWSI (Figure $5 \mathrm{~b}$ ) and therefore no dependence between these parameters is visible. The chart shows that the data measured on 16th August is arranged in two groups with CWSI $\in(-0.075 ;-0.05)$ and with CWSI $\in(-0.025 ; 0)$ and fAPAR in a similar range. The points of these groups correspond to the two transects measured. The difference in CWSI results from slightly different cloud conditions when acquiring LST data over both transects. Data on both transects was obtained within an hour and by covering the Sun with poorly visible high clouds, which shows how important it is to collect data in optimal meteorological conditions. 


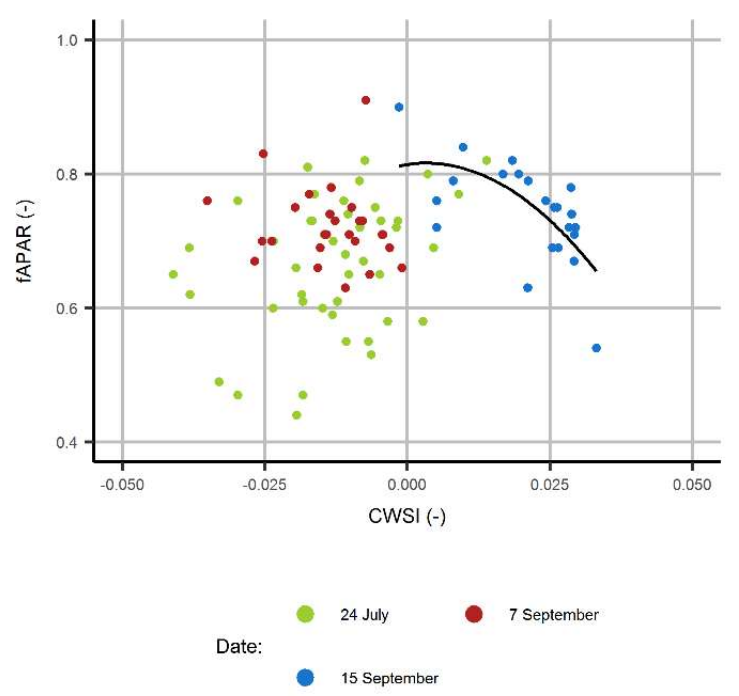

Figure 10. Dependence of fAPAR on CWSI for the Biebrza National Park in 2016, the black line shows the matching quadratic equation for points measured at 15th September

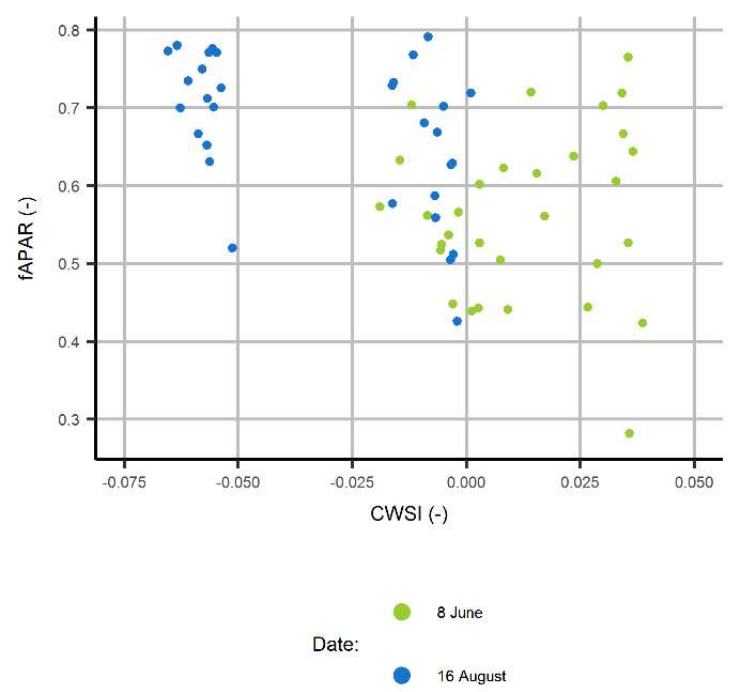

Figure 11. Dependence of fAPAR on CWSI for the Biebrza National Park in 2017

The dependence of CCI on CWSI in 2016 is presented in figure 12, and for 2017 in figure 13. In 2016 (Figure 12), information was obtained in 71 measurement points, in which CCI was changing from 4.6 to 17.2 , while CWSI was changing from -0.041 to 0.024 . The measured relationships do not significantly correlate with each other, yet it can be seen that the chlorophyll content in the studied habitat drops with the increase in CWSI. In 2017 (Figure 13), information was obtained in 62 measurement points, in which CCI was changing from 4.1 to 21.5 , while CWSI was changing from 0.065 to 0.039 . The measurements were carried out in two dates with low CWSI (Figure $5 \mathrm{~b}$ ) and therefore no dependence between these parameters is visible. The chart shows that the data measured on 16th August is arranged in two groups with CWSI $\in(-0.075 ;-0.05)$ and with CWSI $\in(-0.025 ; 0)$ and fAPAR in a similar range. The points of these groups correspond to the two transects measured, located parallel to each other (Figure 4C). The difference in CWSI values results from slightly different cloud conditions when acquiring LST data over both transects. Data on both transects was obtained 
within an hour and by covering the Sun with poorly visible high clouds, which shows how important it is to collect data in optimal meteorological conditions.

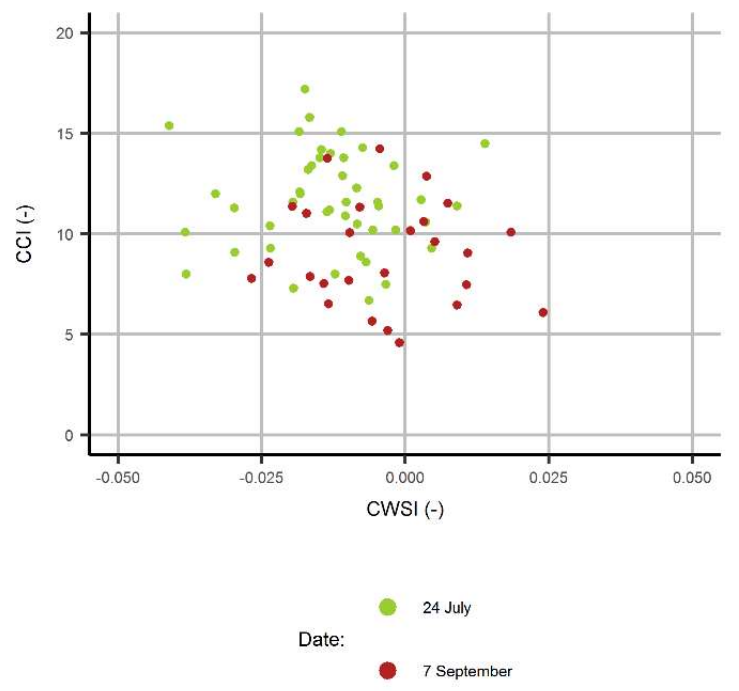

Figure 12. Dependence of CCI on CWSI for the Biebrza National Park in 2016

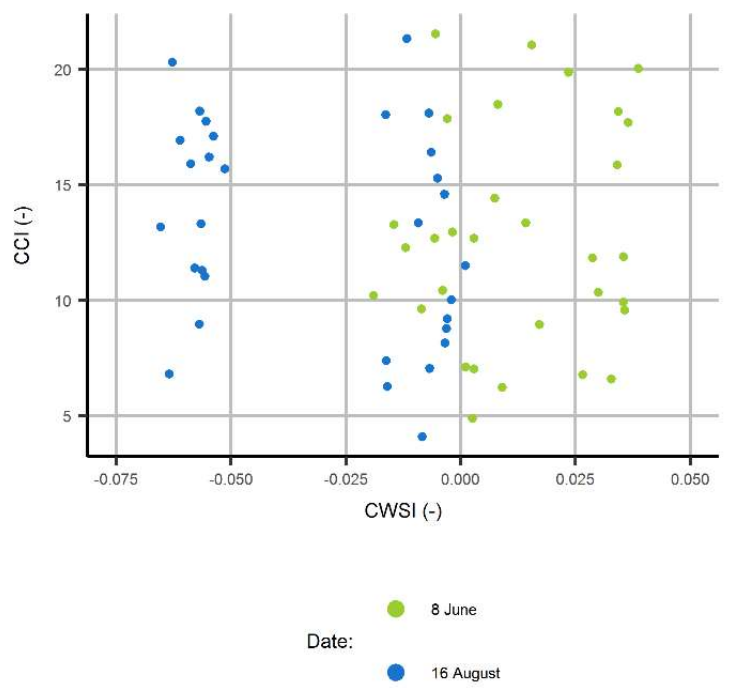

Figure 13. Dependence of CCI on CWSI for the Biebrza National Park in 2017

\section{Conclusions}

The CWSI calculations carried out on two wetland habitats (Natura 2000 code 7140 and 7230) together with the analysis of meteorological conditions and indices of biophysical conditions of plants show the possibility of using CWSI in such habitats. The CWSI values in the studied dates correspond to the overall condition of the plants observed during the measurement campaigns carried out, when measurements were carried out during optimal meteorological conditions. The results of the conducted research show the spatial and temporal variability of CWSI.

The results indicate the need to carry out measurements in ideal meteorological conditions which significantly affect the obtained CWSI values even with small changes. CWSI values obtained were significantly different for UAV flights carried out one after another in a short time (e.g. in the area of the Biebrza on 16th August) in the area remaining in the same state but with a slight change in cloud cover during the flights. 
In habitat 7140, a weak but statistically significant correlation was observed between CWSI values and selected biophysical parameters (fAPAR and CCI). For habitat 7230, only a weak, but statistically significant dependence between CWSI and fAPAR was observed on the day when the drying occurred.

All measurements carried out in two years with very different meteorological conditions (dry year 2016 and wet year 2017) reflect the overall condition of the studied habitat. In 2016, a high variability of CWSI depending on the period of measurements is observed, while in 2017 on all studies objects in all campaigns carried out, CWSI values are similar to each other, while the observed differences are caused by conditions when obtaining remote sensing data. The exception here is the area of the Janów Forest, where clear traces of drying were observed during the maximum temperatures in the summer, 2017.

Areas with a high proportion of sphagnum mosses, which are the first to dry in unfavourable hydrometeorological conditions due to their way of growth leading to the formation of elevated clumps., are challenging to be interpreted. CWSI values in such conditions indicate that the habitat is drying within these clumps despite the fact that the measured values of soil moisture still remain high. In such situations, even a brief change in hydrometeorological conditions (e.g. intensive rainfall, high humidity, presence of dew) causes the clumps to saturate with water and sphagnum mosses to quickly return to good condition. Only long-lasting and persisting unfavourable conditions can change this state both in the sphagnum moss clumps and the entire habitat.

So far, most of the research on the application of CWSI has been conducted in the areas of intensive agricultural economy in crop monocultures. The habitats presented in this publication are heterogeneous plant communities in which the interpretation of the CWSI value often gave rise to some difficulties requiring insight into the species composition of individual research sites (e.g. high proportion of sphagnum mosses and their sensitivity to changing hydrometeorological conditions against the soil moisture measurements). Part of the research questions requires further research on the application of CWSI on wetland habitats particularly sensitive to changes in the water balance, especially in the context of verification of results based on the biophysical parameters used in the research, such as fAPAR or CCI as well as the determination of the drying risk thresholds.

Author Contributions: Conceptualization, Jarosław Chormański; Data curation, Wojciech Ciężkowski, Jacek Jóźwiak and Sylwia Szporak-Wasilewska; Formal analysis, Wojciech Ciężkowski and Jacek Jóźwiak; Funding acquisition, Jarosław Chormański; Investigation, Wojciech Ciężkowski, Jacek Jóźwiak, Sylwia SzporakWasilewska, Małgorzata Kleniewska, Tomasz Gnatowski, Piotr Dąbrowski, Maciej Góraj, Jan Szatyłowicz and Jarosław Chormański; Methodology, Wojciech Ciężkowski, Jacek Jóźwiak, Sylwia Szporak-Wasilewska, Małgorzata Kleniewska, Tomasz Gnatowski, Piotr Dąbrowski, Maciej Góraj, Jan Szatyłowicz and Jarosław Chormański; Project administration, Stefan Ignar; Resources, Wojciech Ciężkowski and Jacek Jóźwiak; Software, Wojciech Ciężkowski and Jacek Jóźwiak; Supervision, Stefan Ignar and Jarosław Chormański; Validation, Wojciech Ciężkowski; Visualization, Wojciech Ciężkowski; Writing - original draft, Wojciech Ciężkowski and Jacek Jóźwiak; Writing - review \& editing, Wojciech Ciężkowski, Sylwia Szporak-Wasilewska, Małgorzata Kleniewska, Tomasz Gnatowski, Piotr Dąbrowski, Maciej Góraj, Jan Szatyłowicz and Jarosław Chormański.

Funding: This research was funded by the project HabitatARS (BIOSTRATEG2/297915/3/NCBR/2016). The innovative approach supporting monitoring of non-forest Natura 2000 habitats, using remote sensing methods financed by The National Centre for Research and Development.

Conflicts of Interest: The authors declare no conflict of interest

\section{References}

1. Spinoni, J.; Vogt, J. V; Naumann, G.; Barbosa, P.; Dosio, A. Will drought events become more frequent and severe in Europe? Int. J. Climatol. 2018, 38, 1718-1736.

2. Schubert, S. D.; Stewart, R. E.; Wang, H.; Barlow, M.; Berbery, E. H.; Cai, W.; Hoerling, M. P.; Kanikicharla, K. K.; Koster, R. D.; Lyon, B. Global meteorological drought: a synthesis of current understanding with a focus on SST drivers of precipitation deficits. J. Clim. 2016, 29, 3989-4019.

3. Trenberth, K. E.; Dai, A.; Van Der Schrier, G.; Jones, P. D.; Barichivich, J.; Briffa, K. R.; Sheffield, J. Global 
warming and changes in drought. Nat. Clim. Chang. 2014, 4, 17.

4. Dai, A. Drought under global warming: a review. Wiley Interdiscip. Rev. Clim. Chang. 2011, 2, 45-65.

5. Dai, A. Increasing drought under global warming in observations and models. Nat. Clim. Chang. 2013, 3, 52.

6. Łabędzki, L.; Bąk, B. Meteorological and agricultural drought indices used in drought monitoring in Poland: a review. Meteorol. Hydrol. Water Manag. Res. Oper. Appl. 2014, 2.

7. Doroszewski, E.; Kozyra, J.; Pudelko, R.; Stuczynski, T.; Jadczyszyn, J.; Koza, P.; Lopatka, A. Monitoring suszy rolniczej w Polsce. Wiadomości Melior. $i$ Łąkarskie 2008, 51. (In Polish)

8. Doroszewski, A.; Jadczyszyn, J.; Kozyra, J.; Pudełko, R.; Stuczyński, T.; Mizak, K.; Łopatka, A.; Koza, P.; Górski, T.; Wróblewska, E. Podstawy systemu monitoringu suszy rolniczej. Woda-Środowisko-Obszary Wiej. 2012, 12, 77-91. (In Polish)

9. Funk, C. New satellite observations and rainfall forecasts help provide earlier warning of African drought. Earth Obs. 2009, 21, 23-27.

10. Svoboda, M.; LeComte, D.; Hayes, M.; Heim, R.; Gleason, K.; Angel, J.; Rippey, B.; Tinker, R.; Palecki, M.; Stooksbury, D. The drought monitor. Bull. Am. Meteorol. Soc. 2002, 83, 1181-1190.

11. Shukla, S.; Steinemann, A. C.; Lettenmaier, D. P. Drought monitoring for Washington State: Indicators and applications. J. Hydrometeorol. 2011, 12, 66-83.

12. Hao, Z.; AghaKouchak, A.; Nakhjiri, N.; Farahmand, A. Global integrated drought monitoring and prediction system. Sci. Data 2014, 1, 140001.

13. Nijssen, B.; Shukla, S.; Lin, C.; Gao, H.; Zhou, T.; Sheffield, J.; Wood, E. F.; Lettenmaier, D. P. A prototype global drought information system based on multiple land surface models. J. Hydrometeorol. 2014, 15, 1661-1676. 14. Ceglar, A.; Medved-Cvikl, B.; Moran-Tejeda, E.; Vicente Serrano, S. M.; Kajfež-Bogataj, L. Assessment of multi-scale drought datasets to quantify drought severity and impacts in agriculture: a case study for Slovenia. Int. J. Spatial Data Infrastruct. Res., (2012), 7, 464-487.

15. Agricultural Drought Monitoring System in Poland (ADMS) http://www.susza.iung.pulawy.pl/en/. (access 30.09.2018)

16. Palmer, W. C. Meteorological drought. Research Paper No. 45. Washington, DC: US Department of Commerce. Weather Bur. 1965, 59.

17. Heim, R. R. Drought indices: a review. Drought a Glob. Assess. 2000, 159-167.

18. Heim Jr, R. R. A review of twentieth-century drought indices used in the United States. Bull. Am. Meteorol. Soc. 2002, 83, 1149-1165.

19. Vogt, J.V., Somma, F. (Eds.), 2000. Drought and drought mitigation in Europe. Advances in Natural and Technical Hazards Research, vol. 14. Kluwer Academic Publishers, Dordrecht.

20. Hayes, M. J.; Alvord, C.; Lowrey, J. Drought indices. Intermt. West Clim. Summ. 2007, 3, 2-6.

21. Niemeyer, S. New drought indices. Options Méditerranéennes. Série A Séminaires Méditerranéens 2008, 80, 267274.

22. Sepulcre-Canto, G.; Horion, S.; Singleton, A.; Carrao, H.; Vogt, J. Development of a Combined Drought Indicator to detect agricultural drought in Europe. Nat. Hazards Earth Syst. Sci. 2012, 12, 3519-3531.

23. McKee, T. B.; Doesken, N. J.; Kleist, J. The relationship of drought frequency and duration to time scales. In Proceedings of the 8th Conference on Applied Climatology; American Meteorological Society Boston, MA, 1993 ; Vol. 17, pp. 179-183.

24. Bloomfield, J. P.; Marchant, B. P. Analysis of groundwater drought building on the standardised precipitation index approach. Hydrol. Earth Syst. Sci. 2013, 17, 4769-4787.

25. Paulo, A. A.; Pereira, L. S.; Matias, P. G. Analysis of local and regional droughts in southern Portugal using the theory of runs and the Standardised Precipitation Index. In Tools for Drought Mitigation in Mediterranean 
Regions; Springer, 2003; pp. 55-78.

26. Guenang, G. M.; Kamga, F. M. Computation of the standardized precipitation index (SPI) and its use to assess drought occurrences in Cameroon over recent decades. J. Appl. Meteorol. Climatol. 2014, 53, 2310-2324.

27. Morid, S.; Smakhtin, V.; Moghaddasi, M. Comparison of seven meteorological indices for drought monitoring in Iran. Int. J. Climatol. A J. R. Meteorol. Soc. 2006, 26, 971-985.

28. Kim, D.-W.; Byun, H.-R.; Choi, K.-S. Evaluation, modification, and application of the Effective Drought Index to 200-Year drought climatology of Seoul, Korea. J. Hydrol. 2009, 378, 1-12.

29. Deo, R. C.; Şahin, M. Application of the extreme learning machine algorithm for the prediction of monthly Effective Drought Index in eastern Australia. Atmos. Res. 2015, 153, 512-525.

30. Łabędzki, L.; Bąk, B. Standaryzowany klimatyczny bilans wodny jako wskaźnik suszy. Acta Agrophysica 2004, 3, 117-124.

31. Hunt, E. D.; Hubbard, K. G.; Wilhite, D. A.; Arkebauer, T. J.; Dutcher, A. L. The development and evaluation of a soil moisture index. Int. J. Climatol. 2009, 29, 747-759.

32. Łabędzki L., Bąk B. Metoda wskaźnikowej oceny i klasyfikacji uwilgotnienia gleb trwałych użytków zielonych w Polsce. Infrastruktura i Ekologia Terenów Wiejskich 2015, III/1, 515-531..(In Polish)

33. Gardner, B. R.; Nielsen, D. C.; Shock, C. C. Infrared thermometry and the crop water stress index. I. History, theory, and baselines. J. Prod. Agric. 1992, 5, 462-466.

34. Maes, W. H.; Steppe, K. Estimating evapotranspiration and drought stress with ground-based thermal remote sensing in agriculture: a review. J. Exp. Bot. 2012, 63, 4671-4712.

35. Irmak, S.; Haman, D. Z.; Bastug, R. Determination of crop water stress index for irrigation timing and yield estimation of corn. Agron. J. 2000, 92, 1221-1227.

36. Erdem, Y.; Erdem, T.; ORTA, A. H.; Okursoy, H. Irrigation scheduling for watermelon with crop water stress index (CWSI). J. Cent. Eur. Agric. 2006, 6, 449-460.

37. Andrews, P. K.; Chalmers, D. J.; Moremong, M. Canopy-air temperature differences and soil water as predictors of water stress of apple trees grown in a humid, temperate climate. J. Am. Soc. Hortic. Sci. 1992, 117, 453-458.

38. Wang, D.; Gartung, J. Infrared canopy temperature of early-ripening peach trees under postharvest deficit irrigation. Agric. Water Manag. 2010, 97, 1787-1794.

39. Berni, J. A. J.; Zarco-Tejada, P. J.; Sepulcre-Cantó, G.; Fereres, E.; Villalobos, F. Mapping canopy conductance and CWSI in olive orchards using high resolution thermal remote sensing imagery. Remote Sens. Environ. 2009, 113, 2380-2388.

40. García-Tejero, I. F.; Rubio, A. E.; Viñuela, I.; Hernández, A.; Gutiérrez-Gordillo, S.; Rodríguez-Pleguezuelo, C. R.; Durán-Zuazo, V. H. Thermal imaging at plant level to assess the crop-water status in almond trees (cv. Guara) under deficit irrigation strategies. Agric. Water Manag. 2018, 208, 176-186.

41. Deverel, S. J.; Ingrum, T.; Leighton, D. Present-day oxidative subsidence of organic soils and mitigation in the Sacramento-San Joaquin Delta, California, USA. Hydrogeol. J. 2016, 24, 569-586.

42. Könönen, M.; Jauhiainen, J.; Laiho, R.; Kusin, K.; Vasander, H. Physical and chemical properties of tropical peat under stabilised land uses. Mires and Peat 2015, 16, 1-13.

43. Hewelke, E.; Szatyłowicz, J.; Gnatowski, T.; Oleszczuk, R. Effects of soil water repellency on moisture patterns in a degraded sapric histosol. L. Degrad. Dev. 2016, 27, 955-964.

44. Kluge, B.; Wessolek, G.; Facklam, M.; Lorenz, M.; Schwärzel, K. Long-term carbon loss and CO2-C release of drained peatland soils in northeast Germany. Eur. J. Soil Sci. 2008, 59, 1076-1086.

45. Mäkiranta, P.; Laiho, R.; Fritze, H.; Hytönen, J.; Laine, J.; Minkkinen, K. Indirect regulation of heterotrophic peat soil respiration by water level via microbial community structure and temperature sensitivity. Soil Biol. 
Biochem. 2009, 41, 695-703.

46. Berezowski, T.; Nossent, J.; Chormański, J.; Batelaan, O. Spatial sensitivity analysis of snow cover data in a distributed rainfall-runoff model. Hydrol. Earth Syst. Sci. 2015, 19, 1887-1904.

47. Chormanski, J.; Okruszko, T.; Ignar, S.; Batelaan, O.; Rebel, K. T.; Wassen, M. J. Flood mapping with remote sensing and hydrochemistry: A new method to distinguish the origin of flood water during floods. Ecol. Eng. 2011, 37, 1334-1349.

48. Keizer, F. M.; Schot, P. P.; Okruszko, T.; Chormański, J.; Kardel, I.; Wassen, M. J. A new look at the flood pulse concept: the (ir) relevance of the moving littoral in temperate zone rivers. Ecol. Eng. 2014, 64, 85-99.

49. Mirosław-Świątek, D.; Szporak-Wasilewska, S.; Grygoruk, M. Assessing floodplain porosity for accurate quantification of water retention capacity of near-natural riparian ecosystems-a case study of the Lower Biebrza Basin, Poland. Ecol. Eng. 2016, 92, 181-189.

50. Kleniewska, M.; Gołaszewski, D.; Majewski, G.; Szporak-Wasilewska, S.; Rozbicka, K.; Rozbicki, T. Diurnal course of the main heat balance components of a marshy meadow in the Lower Biebrza River Valley. Polish J. Environ. Stud. 2015, 24.

51. Ciężkowski, W.; Berezowski, T.; Kleniewska, M.; Szporak-Wasilewska, S.; Chormański, J. Modelling wetland growing season rainfall interception losses based on maximum canopy storage measurements. Water, 2017, $10(1), 41$

52. Berezowski, T.; Chormański, J.; Kleniewska, M.; Szporak-Wasilewska, S. Towards rainfall interception capacity estimation using ALS LiDAR data. In Geoscience and Remote Sensing Symposium (IGARSS), 2015 IEEE International; IEEE, 2015; pp. 735-738.

53. Berezowski, T.; Wassen, M.; Szatyłowicz, J.; Chormański, J.; Ignar, S.; Batelaan, O.; Okruszko, T. Wetlands in flux: looking for the drivers in a central European case. Wetl. Ecol. Manag. 26, 849-863

54. Khanal, S.; Fulton, J.; Shearer, S. An overview of current and potential applications of thermal remote sensing in precision agriculture. Comput. Electron. Agric. 2017, 139, 22-32.

55. Anderson, M. C.; Hain, C.; Otkin, J.; Zhan, X.; Mo, K.; Svoboda, M.; Wardlow, B.; Pimstein, A. An intercomparison of drought indicators based on thermal remote sensing and NLDAS-2 simulations with US Drought Monitor classifications. J. Hydrometeorol. 2013, 14, 1035-1056.

56. Jones, H. G. Irrigation scheduling: advantages and pitfalls of plant-based methods. J. Exp. Bot. 2004, 55, 24272436.

57. Jackson, R. D.; Idso, S. B.; Reginato, R. J.; Pinter Jr, P. J. Canopy temperature as a crop water stress indicator. Water Resour. Res. 1981, 17, 1133-1138.

58. http://klimat.pogodynka.pl/pl/climate-maps/\#Mean_Temperature/Monthly/2010/1/Winter. (acces 30.09.2018)

59. KopeL, D.; Michalska-Hejduk, D.; Berezowski, T.; Borowski, M.; Rosadzifski, S.; Chormafski, J. Application of multisensoral remote sensing data in the mapping of alkaline fens Natura 2000 habitat. Ecol. Indic. 2016, 70, 196-208.

60. Kondracki, J. Geografia regionalna polski; Wydawn. Naukowe PWN, 2000.

61. Kondracki, J. Geografia fizyczna Polski; Państ. Wydaw. Naukowe, 1978.

62. http://www.tpinet.pl. (access 30.09.2018)

63. Skierucha, W.; Wilczek, A.; Szypłowska, A.; Sławiński, C.; Lamorski, K. A TDR-based soil moisture monitoring system with simultaneous measurement of soil temperature and electrical conductivity. Sensors 2012, $12,13545-13566$.

64. Oleszczuk, R.; Brandyk, T.; Gnatowski, T.; Szatylowicz, J. Calibration of TDR for moisture determination in peat deposits. Int. Agrophysics. 2004, 18, 145-152. 
65. Oleszczuk, R., Gnatowski, T., Brandyk, T., Szatylowicz J., 2007. Calibration of TDR for moisture content monitoring in moorsh layers. In: Okruszko, T., Maltby, E., Szatyłowicz, J., Swiatek, D., Kotowski W. (Eds.), Wetlands monitoring, modelling and management. Taylor and Francis Group, London, pp. 121 - 124.

66. Idso, S. B.; Jackson, R. D.; Pinter Jr, P. J.; Reginato, R. J.; Hatfield, J. L. Normalizing the stress-degree-day parameter for environmental variability. Agric. Meteorol. 1981, 24, 45-55.

67. Bellvert, J.; Zarco-Tejada, P. J.; Girona, J.; Fereres, E. Mapping crop water stress index in a 'Pinotnoir'vineyard: comparing ground measurements with thermal remote sensing imagery from an unmanned aerial vehicle. Precis. Agric. 2014, 15, 361-376.

68. Bellvert, J.; Marsal, J.; Girona, J.; Zarco-Tejada, P. J. Seasonal evolution of crop water stress index in grapevine varieties determined with high-resolution remote sensing thermal imagery. Irrig. Sci. 2015, 33, 81-93.

69. http://old.imgw.pl/extcont/biuletyn_monitoringu/ (access 30.09.2018)

70. Miętus, M.; Filipiak, J.; Owczarek, M. Warunki termiczne na obszarze Wybrzeża i Pomorza w świetle wybranych klasyfikacji; IMiGW, 2002. (In Polish)

71. Miętus, M.; Filipiak, J.; Owczarek, M.; Jakusik, E. Zmienność warunków opadowych w rejonie polskiego wybrzeża Morza Bałtyckiego w świetle kwantylowej klasyfikacji opadowej. Mater. Badaw. I M G W, Meteorol. 2005, 37. (In Polish)

72. R Core Team R: A Language and Environment for Statistical Computing 2017. 